\title{
PREFÁCIO: \\ DESAFIOS PARA O TRABALHO COM FAMÍLIAS, EM TEMPOS DE (DES)PROTEÇÕES E JUDICIALIZAÇÕES*
}

Maria Carmelita Yazbek ${ }^{1}$

Este livro, que se apresenta como um resultado dos estudos e debates realizados por docentes e pesquisadoras em Atividade Programada desenvolvida no Programa de Estudos Pós-Graduados em Serviço Social da PUCSP, no segundo semestre de 2019, sob a coordenação da Professora Dra. Eunice Teresinha Fávero, revela-se importante contribuição à tarefa de desvendar algumas questões que permeiam o atual discurso sobre família (s) e gênero; especialmente no âmbito dos Sistemas de Justiça e de (des)proteção Social.

Essa Atividade Programada, como consta da Apresentação da Coletânea, nasceu da preocupação com a intensificação, nos anos recentes, de posicionamentos conservadores em relação à família e gênero com seus impactos nas Políticas Sociais, especialmente naquelas de natureza protetiva. Posicionamentos que também vêm se expressando nas "legislações e trabalho com famílias, no cotidiano de espaços sócio ocupacionais da área sociojurídica e para além dela, na medida de suas interfaces e conexões com outras áreas"

Como sabemos, no atual cenário de ascensão ao poder de forças conservadoras de traços fascistas, configura-se uma paisagem sinistra, caracterizada por tempos de regressão obscurantista, com a criminalização de famílias pobres e de seus filhos, o extermínio de jovens pobres e negros, o acirramento de preconceitos, do assédio, a naturalização de desigualdades, do racismo e da homofobia.

O contexto mais global, é de crise estrutural do capital que avança em seu caráter ultraliberal, predatório e na banalização da vida. São tempos de devastação como nos lembra Antunes, "[...] uma fase ainda mais destrutiva da barbárie neoliberal e financista." (Antunes, 2018, p. 10) Contexto no qual reativase o pensamento conservador, restaurador e defensor da ordem instituída e o pensamento reacionário que confronta valores democráticos e propõe elimina-

*DOI - 10.29388/978-65-86678-28-4-0-f.11-14

${ }^{1}$ Doutora em Serviço Social. Pós-doutoramento no âmbito de ciências políticas pelo Instituto de Estudos Avançados da Universidade de São Paulo - USP. Professora do Programa Pós-Graduado em Serviço Social da PUCSP. 
ção de direitos, especialmente dos segmentos mais pobres e subalternizados da sociedade, onde estão as famílias com as quais os assistentes sociais trabalham. Sabemos que nas últimas décadas o capital financeiro, em sua fase mais destrutiva, assumiu o comando no processo de acumulação e seu domínio sobre o capital produtivo trouxe consequências graves para os trabalhadores pobres e suas famílias, com a manutenção de taxas elevadas de desemprego, insegurança e instabilidade nos empregos, crescimento do trabalho informal e precário, redução de salários e precarização das relações de trabalho. A consequência foi, por um lado, a radicalização da questão social, e por outro, a recomposição das políticas sociais que vem se tornando cada vez mais focalizadas, seletivas e condicionadas, responsabilizando as famílias pobres por sua própria sobrevivência, condição fundamental para expansão do "familismo" no âmbito da Seguridade Social brasileira. Os assistentes sociais fazem parte desse processo, como gestores e operadores dessas políticas sociais e como profissionais do Sistema de Justiça.

Uma das características dessas transformações, é o crescente desfinanciamento das políticas sociais, situação que vem tendendo a se agravar. Como resultado da Emenda Constitucional 95/18 que desqualifica os direitos e impossibilita os serviços de manter a cobertura atual, ao propor o congelamento (com o teto das despesas de 2016 corrigido) das despesas sociais por 20 anos. A Assistência Social vem sendo uma das políticas mais atingidas por esses cortes de recursos prevendo-se para os próximos anos a interrupção do atendimento de 17 mil serviços socioassistenciais, ofertados nos CRAS, CREAS, CENTROPOP e Unidades de Acolhimento Institucional que atuam diretamente em situações de ocorrência de abuso sexual, abandono, situação de dependência, violência doméstica, maus tratos físicos e/ou psíquicos, situação de trabalho infantil, situação de rua, cumprimento de medidas socioeducativas, entre outras situações de violação dos direitos. Esses cortes inviabilizarão a oferta de serviços, programas e projetos às famílias e indivíduos pertencentes às classes subalternizadas de nossa sociedade, apontando para uma conjuntura de embate em que são confrontados dois projetos de proteção social no Brasil: um minimamente referenciado às promessas constitucionais de cidadania e direitos na perspectiva de um Sistema de Proteção Social público, universal e de afirmação de direitos; e outro, que se configura em seu "oposto" que reduz a Proteção Social à reiteração de práticas conservadoras, que remetem sob novas formas à seletividade $\mathrm{e}$ focalização meritocrática no sistema protetivo.

Nesse quadro, como aponta Fávero, na apresentação deste livro, vem ocorrendo a judicialização de diversas situações e expressões da questão social, 
que atingem a vida de famílias com as quais trabalham os assistentes sociais nas Políticas Sociais e no espaço do sistema de justiça, "tanto para assegurar direitos legalmente dispostos, como para punir eventuais comportamentos, ações ou omissões de sujeitos acusados por infração, ou suposta infração da lei, conforme a sua interpretação".

Em síntese, o trabalho do assistente social no sistema de justiça vem se deparando crescentemente com diversas expressões da questão social que, judicializadas, ocultam as contradições constitutivas de uma ordem social marcada pela desigualdade, pela pobreza, como questão de classe, pelo preconceito, pelo racismo, a exclusão e a homofobia, configurando o avanço do pensamento conservador e irracional, em diferentes planos da vida.

É a partir destes referentes e nos marcos de um Serviço Social comprometido com a construção de outra ordem societária, que vão se inscrever as possíveis análises e respostas profissionais a esse contexto, expressas nos sete trabalhos que compõem esta Coletânea e que, exemplarmente, buscam decifrar e expressar a realidade do trabalho profissional especialmente no âmbito do sistema de justiça, onde o Serviço Social enfrenta inúmeros desafios, em diferentes planos.

Destacamos nesses artigos a análise de Regina Célia Tamaso Mioto sobre a Proteção Social à Família brasileira com ênfase nos aspectos conceituais, colocando em evidência que diferentes concepções de família sustentam diferentes projetos de proteção social, destacando algumas características do ideário sobre a família presentes no discurso político e social oficial do país. O trabalho de Juliana Maggi Lima que problematiza avanços e retrocessos no âmbito do Direito Familiar sob os impactos do avanço do conservadorismo, e o artigo da professora Graziela Acquaviva que nos apresenta um fundamentado debate acerca da temática de gênero e de violência doméstica e familiar, sob a ótica do tensionamento proteção/desproteção, presente na Legislação protetiva, destacando suas contradições na Lei Maria da Penha e no trabalho no âmbito do Sistema Único de Assistência Social. O artigo de Rita C. S. Oliveira, nos apresenta, neste livro, importante análise acerca da Perícia Social nas disputas judiciais de guarda, trazendo ao debate o Serviço Social evidenciando que tal contexto favorece o olhar psicologizante para tais fenômenos e a "emissão de juízos de valor sobre ser mãe/pai, como cuidar e se relacionar com filhos(as)". O exercício profissional é também o foco do artigo de Andreia Pequeno que vai enfatizar o trabalho do assistente social em situações de curatela e de interdição à luz da Lei Brasileira de Inclusão. Ainda na perspectiva do Serviço Social, temos o trabalho da organizadora da Coletânea, Eunice Fávero, que vai abordar a temática 
da judicialização da atenção a crianças, adolescentes e famílias, tendo como referência a relação com a proteção integral e a desproteção social. Finalmente, Gracielle Feitosa de Loiola e Thaís Peinado Berberian nos mostram em seu trabalho, o doloroso processo de produção sociojurídica de "famílias incapazes" e "negligentes" no atendimento de necessidades de suas crianças e jovens no Sistema de Justiça e na rede socioassistencial, com a qual se relaciona.

Em síntese, estamos diante de um livro organizado por uma intelectual que é referência na temática abordada, composto por textos instigantes e mobilizadores, que problematizam conceitos e a realidade, enfrentam polêmicas e nos levam a levantar novas questões, tratando-se de leitura obrigatória para todos que buscam enfrentar e minimizar as injustiças do tempo presente.

\section{Referência}

ANTUNES, Ricardo. Prefácio. In: RAICHELIS, Raquel; VICENTE, Damares; ALBUQUERQUE, Valéria (Orgs.). A nova morfologia do trabalho no Serviço Social. São Paulo: Cortez Editora, 2018. 